\title{
CONCEPTUAL ORIGINS OF LEGAL LINGUISTICS
}

\author{
MARCUS GALDIA \\ Dr. phil., Dr. iur., Associate Professor of Law \\ International University of Monaco \\ 14, rue Hubert Clérissi \\ MC 98000 Monaco \\ mgaldia@monaco.edu
}

ORCID: https://orcid.org/0000-0003-0490-5213

\begin{abstract}
This essay is a survey of methods applied and topics scrutinized in legal-linguistic studies. It starts with the elucidation of the epistemic interest that led to the emergence and to the subsequent expansion of the mainstream legal-linguistic knowledge that we dispose of today. Thus, the essay focuses upon the development of problem awareness in the emerging legal-linguistic studies as well as upon the results of research that might be perceived as the state of the art in the mainstream legal linguistics. Meanwhile, some methodologically innovative tilts and twists that enrich and inspire contemporary legal linguistics are considered as well. Essentially, this essay traces the conceptual landscape in which the paradigms of legal-linguistic studies came about. This conceptual landscape extends from the research into the isolated words of law and the style used by jurists to the scrutiny of legal
\end{abstract}


texts and legal discourses in all their socio-linguistic complexity. Within this broad frame of reference, many achievements in legal-linguistic studies are mentioned in order to sketch the consequences of processes in which legallinguistic paradigms take shape. The author concludes upon a vision of legal linguistics called pragmatic legal linguistics as the newest stage in the intellectual enterprise that aims to pierce the language of the law and by so doing to understand law better.

Keywords: inquiries into the language of law; legal linguistics and its method; legal-linguistic topics; mainstream legal linguistics; future legal linguistics.

\section{Introduction}

The scrutiny of legal language in scholarly contexts begins with the upcoming of the epistemic interest in legal-linguistic matters. This interest could not have been satisfied in the existing areas of knowledge, and most prominently not in the legal doctrine, which focused upon the content of legal regulation and not upon the way in which this regulation was communicated. Therefore, a heuristic leap became necessary in order to create an area of knowledge in its own right in order to answer the questions that emerged when interested linguists and other social scientists approached the language of law. As so often, this new area of knowledge that is called here legal linguistics did not emerge all at once. It passed stages, often perceived as final yet finally proven temporary, such as the interdisciplinary law and language studies to reach higher and to reach wider. In order to accomplish the task to create a new area of knowledge the legal linguists needed a method. However, this method could not be purely linguistic, nor could it be purely legal as our experience teaches us that these methods do not allow to answer the most pertinent legal-linguistic questions. Hence, legal linguists needed to reach beyond the methodological fields of linguistics and of legal studies to formulate a set of methodological presuppositions that could be called legal-linguistic. Thus, preliminary methods were hammered out from the amalgam of different areas of knowledge and from methodological approaches that allowed the legallinguistic research to continue in a more systematic way.

Following their preliminary methods, the pioneers of legal linguistics such as David Mellinkoff, Gérard Cornu, Edeltraud Bülow, 
Heikki E.S. Mattila, and Peter M. Tiersma approached the legal language and described its characteristic features. Initially, legal linguists determined the vocabulary of law as the domain of their specific interest. Soon, however, they had to adjust their narrow concept of legal language to the results of their studies. They had to broaden their approach to legal language and cover more than the vocabulary of law that many of them determined rather strictly. This meant that a move became necessary from vocabulary that was exclusively legal, for instance promissory estoppel, to the words of law in broader contexts, such as accident that appear in legal settings, yet not exclusively. Furthermore, the initial interest in the legal style led them to consider wider linguistic units that transgress the limits of isolated vocabulary, and that consist of lexemes and syntagmas that constitute legal terms. Legal linguists discovered that legal terminology, which stroke them first, functions within broader linguistic structures and that it is better understood within them than in isolation. These broader linguistic structures were texts, written and oral. Yet legal texts proved multifaceted so that their further classification into legal text types became necessary to explain how the legal language works. It became also apparent that not the legal terminology, but the legal text type constitutes the main problem in the understanding of legal texts. Nowadays, in the epoch marked by the internet an unknown word in a legal text can be relatively easily elucidated by the speaker, yet textual structures in which law is expressed are more challenging because law manifests itself in systematically interrelated textual units, such as provisions in a legal code. Interrelations of textual structures are not visible in texts and therefore cause problems in their understanding. No easily available factual knowledge on the screen of a smartphone enables us to explain such structurally complex textuality of law. This discovery concerns both professionals of law and lay persons because both are able to cope with unknown words, yet they are much less expert in handling complex textual structures. What is more, legal texts are not static and preformulated. They emerge in legal discourses that shape legal texts, both oral and written. The understanding of processes in which law is formed and applied linguistically equals the understanding of law in legal linguistics. This, in short, is the first stage of the formation of legal-linguistic knowledge available today. In the following, I will expand the issues sketched above, then critically address some of the classical legal-linguistic findings and their deficits. I will also mention certain promising developments in contemporary 
legal-linguistic research and sketch a specific area in legal-linguistic studies that integrates and broadens the discussed topics and that I call pragmatic legal linguistics. Meanwhile, I will not discuss the conception and the achievements of pragmatic legal linguistics in this essay, mainly due to space concerns. I will come back to it in another publication.

As far as the structure of my essay is concerned I would like to mention what follows: In footnotes to the main text, the reader will find examples of legal-linguistic reasoning and small case studies that make clearer how the legal linguist works. Throughout the text, new terms will be italicized whenever they appear for the first time. Occasionally, summaries of the state of the art concerning the specific topic in question will appear in footnotes as well. Additionally, surveys of scholarly writings that render most important research concerning the discussed topic will be treated in the footnotes to the main text. The footnotes do no aspire to exhaust the topic addressed in them, yet they enable at least the first orientation in the legal-linguistic debate about it. Finally, there is reason to mention that the author while trying to state the results of the mainstream legal-linguistic research needed to take a distance from his own point of view upon certain legal-linguistic matters. Indeed, the author does not belong, nor is he perceived in legallinguistic writings as belonging to the mainstream legal linguistics. He represents an alternative approach to mainstream currents that might be called pragmatic legal linguistics, which in his works uncompromisingly appears as critical legal discourse.

Now, it is time to start discussing in more detail what was sketched in the above outline of legal-linguistic developments and focus upon the stages in which contemporary legal linguistics was formed. I propose to start with a chronologically structured overview that is based on my participation in legal-linguistic studies, first as a university student and then as a researcher, during the past forty years. Looking back, I am grateful for the unique opportunity that I had to witness some of the developments that I now describe in proximity to many eminent legal linguists. 


\title{
Emergence of interest in legal-linguistic subject matters
}

\author{
The emergence of the area of scholarly studies called legal linguistics \\ in the twentieth century was caused by the increased interest of linguists \\ and legal theoreticians in the role that language plays in law. ${ }^{1}$ Jurists,
}

${ }^{1}$ The most striking legal-linguistic issue that attracted the attention of researchers and
caused the emergence of legal linguistics was semantic in nature. It concerns primarily
the application of law that is perceived not only by legal linguists as the central issue in
legal science and in legal linguistics. For some scholars, law appeared as a matter of
words, for others as a matter of a specific style of reasoning expressed in a language
build up around conceptual structures. This type of semantic interest in legal-linguistic
matters is valid even today, although its consequences reach nowadays further than in the past when it was originally apprehended. Therefore, one can explain it with the help of a contemporary case. Regularly, the legal linguist will be captivated by the wording of a statute in relation to its application in a case. A typical interpretive dilemma may illustrate this problem: Police units in the U.S. frequently involve dogs when arresting suspects. What follows from the legal regulation when a police dog bites a suspect? In South Carolina, there is statutory law concerning liability for dog bites. According to the South Carolina State Statute 47-3-110, "whenever any person is bitten or otherwise attacked by a dog while the person is in a public place or is lawfully in a private place, including the property of the owner of the dog or other person having the dog in his care or keeping, the owner of the dog or other person having the dog in his care or keeping is liable for the damages suffered by the person bitten or otherwise attacked." Does this provision concern our case? The arrested suspect who was bitten by a police dog would probably say yes and refer to the wording of the statutory provision. At least, he could claim, nothing in the provision's wording contradicts the assumption that police dogs are concerned by it as whatever other dogs. The police would probably say no and explain that the statutory provision does not concern police dogs acting in the line of duty. Best linguists will not be able to answer the question whether the provision concerns police dogs. The reason for this intricacy is that we do not have to do in this case with a linguistic, but with a legal-linguistic question. Judges are better qualified to answer such questions than linguists. Yet they will not be able to provide an unequivocal and generally accepted answer to our question either. Therefore, legal linguists analyse the knowledge that judges have about law and the linguistic form of expression of the knowledge that judges apply in their judgments. They are interested in the way how judges determine the meaning of such provisions and authoritatively answer questions such as the one asked in this case. Meanwhile, the task of legal linguists is not to solve the semantic question for the judge but to research meaning alternatives in legal texts and to use the results of their inquiries in order to construct the theory of the legal language. In the context of our case, legal linguists will also take into consideration that the South Carolina legislator perceived the provision in question as ambiguous. Since 2013, an amendment makes an exception for certified, on duty police dogs responding to lawful commands or otherwise acting in accordance with their training. According to the new provision, both dog and handler must follow policy and may not use excessive force. Otherwise, the police will be liable for dog bites. Furthermore, legal, and not legal-linguistic, are for instance questions such as whether 
at least good jurists, were since antiquity aware of the particular role of language in law, yet they approached language intuitively or at best with the means of philosophical analysis that was impressive yet usually much too general to capture the specific features of the legal language. Historically, the main area of interest of jurists was the question of what the legal regulation says, for instance that regular speed on roads in towns is limited to fifty kilometers per hour. Questions of this sort dominate the view of many jurists upon law even today. Doubtless, jurists dealt also with communicative aspects of law, yet largely on the margin of their studies. The reason for this discrepancy seems to be that the legal science lacked a suitable method to approach law in its linguistic dress. General linguistics of the last century, starting with structuralism, generative transformational grammar, neo- and poststructuralism, and later also general semiotics, linguistic pragmatics, discourse theory, and cognitive linguistics provided more appropriate linguistic research matrices to approach the specific object of studies that was called legal language in a theoretically better founded way. Applied linguistics, with its experience in terminological research, translation, and glottodidactics contributed additional theoretical knowledge that channeled legallinguistic interests into a form of expression that enabled the incorporation of the legal-linguistic research into broader contexts of social sciences. This channeling of intuitive and spontaneous interest of jurists and social scientists in the language of law gave rise to the abundant legal-linguistic research available today. This research has a two-fold structure that makes the form of expression in legal linguistics better understandable. Particularly, some legal linguists perceived legal linguistics as a complementary area of knowledge to the existing legal theory and to the legal doctrine that dominates the study of law. Other legal linguists reflected upon the emergence of the interest in legallinguistic subject matters more critically and stressed the deficits of the traditional legal doctrine and the overly broad and undetermined approach to legal language in the mainstream legal theory as driving

claims for compensation in cases such as ours are usually decided by judges or whether they are practically settled out of court as well as the amount of damages paid to victims of police dog bites. The newspaper Greenville News reported in 2013 that out of court settlements between the South Carolina police and victims of police dog bites may amount to three hundred thousand dollars in a case. This may be an interesting piece of news for a lawyer, but it is not an information apt to attract the attention of a legal linguist. 
forces behind the efforts to come to terms with the legal language. Indeed, traditional legal studies proved largely deficient in this respect as they mainly exposed the linguistic character of law, both in teaching and in research, yet were not able to interpret convincingly the issues that they discovered. In fact, law is a linguistic phenomenon because it manifests itself linguistically and in no other way. It does not make much sense to research it as something else. Meanwhile, jurists who researched law, i.e. its language, as they could not research anything else, approached the language of law using all but linguistic methods. Their methods were mainly limited to positivist doctrinal studies that reach down to the Middle Ages. It cannot surprise that such largely implicit methodology could not satisfy legal-linguistic ambitions. At this point, legal linguists emerged in their quality of scholars who were able to identify, to address, and to clarify issues discovered in doctrinal and general legal-theoretical studies. Legal linguistics was beginning to take shape. Meanwhile, already at the very inception of the legallinguistic research activities two types of interest in legal-linguistic matters became distinctive in different sorts of legal-linguistic studies that today represents either affirmative or critical positions in the research into the legal discourse. Therefore, paradigmatically, all research into the legal language can be divided along ideological lines as either affirmative or critical of law and its institutions. Finally, in terms of heuristics, it is necessary to stress that legal linguistics due to specific conditions in which the interest in the legal-linguistic matters emerged was not a mechanical application of linguistic knowledge upon law but an attempt to create a new area of knowledge that would clarify problems discovered by inquisitive jurists and linguists. Not only in this sense, yet also in this sense, it became a truly fascinating area of intellectual exploration.

\section{Expansion of problem awareness in legal-linguistic studies}

The upcoming of the interest in legal-linguistic matters led the researchers to dealings with topics that they identified as central and therefore worthwhile accurate scrutiny. It seems that the particular vocabulary of jurists, perceived by some as cryptic, was the starting 
point for many to deal with the language of law. ${ }^{2}$ For others, the legal style was decisive for the determination of the nature of the legal language that began to emerge from the growing number of publications on both named topics since the second half of the nineteenth century, mostly in Europe. ${ }^{3}$ Both topics corresponded to interests in issues that might have been termed linguistic in the legal positivism of the nineteenth century. Legal positivists were particularly interested in a better, which meant for them a more precise wording of statutes because they hoped that linguistically precise formulations might solve the problem of the application of law. Since antiquity, the task of the application of abstractly stated law to a case that the judge was expected to decide was perceived as cumbersome. Therefore, nineteenth century's legal positivists hoped that when the legal language, which for them consisted of legal concepts would become unequivocal, all problems of law would be solved or at least simplified. Today, we know that all these hopes were vain as language cannot be artificially predetermined and semantically frozen. Even the most precise legal concepts will always remain undetermined in a certain sense. The discussion about the legal style was conducted with the same positivist idea in mind. It was assumed in it that the more precise the ways of expression of law in statutes and court opinions would be, the higher would also be the degree of legal certainty in legal decisions. At this time, jurists started to write about the legal language. This type of writings, however, is not perceived by me as belonging to legal

\footnotetext{
2 The classic of the French legal linguistics, Gérard Cornu (2005: 13; 62-65), determined the vocabulary of law as primarily consisting of terms exclusively used in law such as antichrèse, nantissement, synallagmatique, and irréfragable. Meanwhile, he had to revise and to broaden his appealing theoretical conception as he soon realized its epistemic limits. Today, the vocabulary of law may comprise whatever lexical unit that becomes relevant in a legal context, for instance mother-in-law, water, and accident. In contemporary legal linguistics, the language of law can be defined only functionally and contextually.

${ }^{3}$ Legal style, defined in early studies rather arbitrarily, interested predominantly jurists who wrote about law. Cf. Louis de Geer. 1985 (1853). Om den juridiska stilen, Stockholm: Rediviva; Birger Wedberg. 1928. Lagstil. Några citat och reflektioner. Stockholm: Norsted; Hans Dölle. 1949. Vom Stil der Rechtssprache. Tübingen: Mohr Verlag; Pierre Mimin. 1970. Le style des jugements. $4^{\text {th }}$ ed. Paris: Librairies Techniques; François-Michel Schroeder. 1978. Le nouveau style judiciaire. Paris: Dalloz; Henry Weihofen. 1980. Legal Writing Style. $2^{\text {nd }}$ ed. St. Paul: West Publishing Co. In terms of the legal-linguistic method, it might be perceived as controversial whether these publications belong to legal linguistics. Contemporary approaches to legal style are methodically more precise (cf. Mattila 2018: 113).
} 
linguistics as it lacks any theoretical anchorage in linguistic methods and displays spontaneous and speculative linguistic thought. These writings are however an object of legal-linguistic studies as researchers might discover in them numerous points of anchorage that shaped the processes in which many central legal-linguistic inquiries emerged. ${ }^{4}$ Last but not least, the intensification of research into legal translation and the practical needs to know this area better led legal linguists to another central traditional legal-linguistic topic. It was discovered or rather made explicit that legal translation is specific in the sense that legal languages that function communicatively in legal systems may prove conceptually incongruent when compared for translation purposes. ${ }^{5}$ More generally, it was claimed in the more recent part of the discussion about the legal translation that the legal language did not know any uniform system of conceptual reference. ${ }^{6}$ Therefore, the idea came up that legal translation was an impossible undertaking, at least theoretically (cf. Galdia 2017: 270-277). Meanwhile, the very existence of many usefully translated legal texts and the possibility to correct existing legal translations suggested rather the contrary theoretical option. Indeed, the skopos-theory developed in general translation studies proved instrumental in solving the most fundamental problem

${ }^{4}$ I may mention for instance: Martin Grunau. 1961. Spiegel der Rechtssprache. Flensburg: Verlag Kurt Gross; Fritz Schönherr. 1985. Sprache und Recht. Aufsätze und Vorträge. Wien: Manz'sche Verlags- und Universitätsbuchhandlung; Bernhard Großfeld. 1990. Unsere Sprache: Die Sicht des Juristen. Opladen: Westdeutscher Verlag. Furthermore, Bernhard Großfeld"s "Sprache und Schrift als Grundlage unseres Rechts", in Juristenzeitung 1997/633, and his numerous other writings that emerged beyond the paradigm of linguistics became influential among jurists and marked the upcoming of the interest in legal-linguistic matters also among legal scholars dealing predominantly with doctrinal issues. Additionally, in Großfeld's writings the link to comparative law appears in a way that became later paradigmatic within comparative legal-linguistic studies. In the contemporary discussion, these issues were expanded and cover the relations between legal cultures and legal languages (cf. Husa 2015; 2020).

${ }^{5}$ In the way of example, for the common law term promissory estoppel there is no direct equivalent term in the legal languages of the civil law. In the translation of a text including this term the legal translator will have to create a new term that should best represent the original term in the target language. In the language of chemistry, such problems do not exist. Every chemical term, for instance carbon monoxide can be unequivocally rendered in whatever other language that disposes of chemical terminology, for instance in Chinese as 一氧化碳 (yī yăng huà tàn).

${ }^{6}$ Using semiotic terminology, Louis Beaudoin spoke about the "absence of universal operational referents" in legal translation, cf. his Legal Translation in Canada, in The Development of Legal Language, ed. H.E.S. Mattila, 2002, 115-130. Helsinki: Kauppakaari. 
of legal translation. It maintained that the total equivalence of the source and the target language in translation cannot be expected. Meanwhile, when the specific task facing the translator was duly determined than translation became possible, and even satisfactory. Thus, the original fundamental problem of legal translation was solved, and the theoretical objection demystified as a misunderstanding. In fact, certain theoreticians of legal translation all too often adopted a concept of equivalence that did not suit natural languages. They confused mathematical sameness (a sort of logical identity) with communicational equivalence that functions in the languages that we speak daily as well as in the legal language. Hence, the way to build up a theory of legal translation was laid bare through this clarification and legal translation developed into a particular area in legal linguistics that dominates the work of many legal linguists. ${ }^{7}$ This theory characterized the nature of legal translation and developed additional topics that are discussed today, such as quality assurance and the use of translation tools. ${ }^{8}$ This state of affairs is encouraging because legal linguistics proves in its abundant legal-translatorial research its relevance to society. On the other hand, by stressing or over-stressing the legaltranslatorial component, legal linguistics might divert attention from many other, no less relevant legal-linguistic topics and problems. It is therefore necessary to maintain that legal linguistics cannot be reduced to issues of legal translation, which, in turn, should not be neglected in it either.

As a result of these developments, around the first half of the twentieth century many legal linguists had the impression that they identified the most pertinent areas of legal-linguistic scrutiny, i.e. the legal terminology and the legal style as constitutive of the legal language, and the problem of terminological equivalence in legal translation. Parts of the contemporary legal-linguistic research still displays the anchorage in this sort of problem awareness, sometimes however on a different, and higher level of abstraction. Meanwhile, the

\footnotetext{
7 Theoretical aspects of legal translation, and especially efforts to structure the translation act were conceptualized in Aleksandra Matulewska's parametric theory of legal translation (cf. Matulewska 2013). They were further expanded in the conception of the general legilinguistic translatology (cf. Kozanecka et al. 2017).

${ }^{8}$ Cf. Fernando Prieto Ramos. 2015. Quality Assurance in Legal Translation: Evaluating Process, Competence and Product in the Pursuit of Adequacy, International Journal for the Semiotics of Law vol. 28 (1), 11-30; Marcus Galdia. 2013. Strategies and Tools for Legal Translation, Comparative Legilinguistics vol. 16, 13-29.
} 
initial interest in the scrutiny of isolated legal terms that corresponded to legal concepts researched by jurists proved disappointing as the linguistic knowledge of the characteristic features of language contradicted the hopes of legal positivists. Additionally, the interest in the legal style appeared disenchanting as traditional methods of the analysis of style did not bring any results that could support the thesis of the particularity of legal language. Therefore, broader conceptualizations of topics, i.e. the expansion of the epistemic interest in the legal language from style to text had to follow suit. However, also issues concerning the structure, the scope and the aims of legal linguistics became an issue for scholarly debates. Let us now have a look at these problems that are closely related to material issues discussed above. As a matter of fact, both topics concern problems of the legal-linguistic method.

\section{Legal linguistics is not alone}

Although sometimes underestimated, the non-doctrinal interest in the language of law led more or less simultaneously to the emergence of different, not only strictly legal-linguistic approaches aiming at elucidating the language of law. Next to legal linguistics, law and language studies and forensic linguistics emerged in different epistemological and paradigmatic contexts (cf. Gibbons 2003; SalmiTolonen 2008). Law and language studies that are an Anglo-American specialty aimed to establish a dialogue between jurists and linguists on issues of their common interest. ${ }^{9}$ Originally, in these studies jurists and linguists were expected to discuss issues of common interest from the

\footnotetext{
${ }^{9}$ Interdisciplinary law and language studies, sometimes transformed in the respective publications into 'language and law' or 'language in law' studies can be approached in: Frederick Schauer, (ed.). 1993. Law and Language. Aldershot/Hong Kong: Dartmouth; Peter M. Tiersma, Lawrence M. Solan (eds.). 2012. The Oxford Handbook of Language and Law. Oxford: Oxford University Press; and Ekkehard Felder, Friedemann Vogel (eds.). 2017. Handbuch Sprache im Recht. Berlin: Walter de Gruyter. In times of expanding systematic legal-linguistic studies, traditional law and language or language and law studies are apparently losing their impact as they cannot transgress their selfimposed methodological limitations. They may be useful in rendering the state of the art in a subsegment of legal-linguistic inquiries, yet they are methodically regressive as far as the conception of the project of legal linguistics is concerned.
} 
position of their respective methodical approaches to the discussed subject matter. Today, law and language studies are also practiced by specialists who regularly deal with issues discussed in legal linguistics. Forensic linguistics emerged as a practical area where linguists were assisting judicial institutions and the police in solving problems of these institutions while using their professional knowledge. Particularly important in it became speaker and author identification. In analogy with the law and language studies, many forensic linguists deal today also with topics created in legal linguistics, yet they maintain their interest in the practical application of linguistic knowledge in cooperation with juridical institutions. Legal linguists do not shy away from contacts with authorities and they also provide assistance to them, yet this type of assistance is not their primary concern. In fact, not every inquiry into the legal language belongs to legal linguistics. This does not mean that approaches to the legal language developed within other than legal-linguistic paradigms would be irrelevant. They are rather complementary as they show the multitude of perspectives and topics that the legal doctrine as the main representative of the legal science was inclined to deny or to neglect.

\section{The naming issue}

As was shown above, legal linguistics is not isolated among the areas of knowledge interested in the scrutiny of legal language. This is a positive trait in the development of research activities because generally, when seen from the perspective of legal linguistics, whatever sort of interest in legal language is valuable. Yet, as this interest manifests itself in different colors, it becomes urgent to deal with the issue what legal linguistics is and what it is not. The beginning of any research activity in different parts of the world and by disconnected researchers or groups of researchers may cause terminological differences that may be methodically relevant or largely negligible. This is also the case in the research into the language of law. This question concerns in legal-linguistic studies the so-called naming issue. The issue as such is not solved today. We can assume that the term legal linguistics emerged in Continental Europe. Its first users were Continental Europeans who also used the English language in their 
writings. The original term was particularly productively used in France as linguistic juridique and in Germany as Rechtslinguistik, which was defined in the legal-linguistic lectures by Edeltraud Bülow. In numerous European countries, the term was used in literal translations

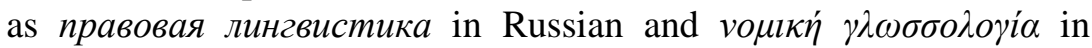
Greek. In China, the term falü yuyanxue (法律語言學/法律语言学) is used (cf. Galdia 2017: 72-73). In Poland, next to general legal-linguistic studies called juryslingwistyka, the Poznań school of legilinguistics emerged as a specific current of general legal-linguistic studies. As of today, it parametrized the legal translation, it clarified the deontic modality in the legal language, and the general communicative aspects of law as well as its specifics stated in the plain language attempts. Scandinavian countries, following Heikki E.S. Mattila's Finnish term oikeuslingvistiikka coined equivalents such as the Swedish rättslingvistik. In his English language treatises, Mattila started to call his multilingual studies of the legal language comparative legal linguistics. In the English-speaking world, the term legal linguistics is also used, although law and language studies remain popular there, especially among researchers who deal only occasionally with legallinguistic issues. It also remains in use for administrative purposes, for instance in university libraries, where European legal-linguistic research is classified as law and language studies. Yet, legal linguistics is not a matter of scattered words but a discipline that researches legal language methodically. Therefore, decisive for the naming of such activities is the methodological choice exercised by the researcher and not artistic concept creation. I assume that in the future course of the development of the discipline also its name will be terminologically consolidated. Meanwhile, the most important thing is that the research object and the method applied in its scrutiny would be clearly expressed in its name, whatever the final choice will be. Meanwhile, due to the approximation of positions in legal linguistics, law and language studies and forensic linguistics also their merger could be discussed. ${ }^{10}$ The new consolidated discipline would be better visible among existing areas of knowledge and would become stronger in terms of its possible impact upon governmental institutions and upon society at large.

\footnotetext{
${ }^{10}$ Such tendency could be seen, for instance, in the publication by Friedemann Vogel (ed.). 2019. Legal Linguistics Beyond Borders: Language and Law in a World of Media, Globalisation and Social Conflict. Berlin: Duncker \& Humblot. Cf. also Marijana Javornik-Čubrić. 2018. Što je pravna lingvistika, Lingua Montenegrina vol. 22, 31-37.
} 


\section{Retrospective upon the origins of legal-linguistic reflection}

Methodological choices exercised by researchers are best understood towards the background of conceptualization efforts around the language of law. History of reflection about the role of the language in law is different from the history of the scholarly discipline called legal linguistics. Direct reference concerning the language of law can be made to ancient Greek orators such as Corax of Syracuse as well as to the writings of the ancient Roman jurists. What is more, Confucian writings include in 論語 Lun $Y u$ (ch. XIII, 3) the doctrine of the rectification of names, (正名 zheng ming), which is fundamental to the Chinese reflection upon language, also in legal contexts. Later, in the Middle Ages, Thomas of Aquino shaped the medieval ideology of law for the Occidental world. It is also important to stress that judges, notably common law judges, in their legal opinions expressed thoughts that imply contemporary, much more explicit and theoretically betterfounded legal-linguistic concepts. Generally, therefore, wherever in antiquity and in the Middle Ages dialectic and rhetoric issues were mentioned in contexts of the shaping or of the application of law, one may perceive such writings as belonging to the history of the legallinguistic thought, although in different degree of immediate influence

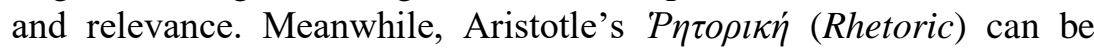
called the bible of the legal linguist as it marks the beginning of the theoretical inquiry into the legal language and it also anticipates many legal-linguistic topics.

Dealing with legal-linguistic roots documented in scholarly writings is difficult because frequently the work in question does not concern primarily the legal language. For instance, the Latin treatise called Rhetorica ad C. Herennium, written some 80 years BOE, deals with general issues of classical rhetoric. Yet it also mentions, although marginally, issues of utmost importance for legal-linguistic studies. This situation continues until our own day. Important legal-linguistic knowledge is often mentioned on the margin of studies that deal with the legal doctrine and with general legal theory by scholars who do not call themselves legal linguists. Therefore, legal linguists have to distill legal-linguistic knowledge from these works that are only implicitly legal-linguistic. Yet these works should not be neglected because they provide valuable observations and illustrative samples of the legal 
language. Therefore, when seen in the historical perspective, the intellectual frame of reference of legal linguists appears uneven, because their anchorage in linguistics and in legal studies differs considerably. ${ }^{11}$ Meanwhile, it is possible to reconstruct a set of theoretical postulates that have their roots in some classics of legal theory, legal semiotics, and general linguistics. These postulates are fundamental to the development of a fully-fledged legal linguistics of the future. Next to these classical fundamentals, contemporary theoretical claims inspire or at least should inspire new generations of legal linguists.

\section{Legal linguistics and legal semiotics}

Studies that call themselves legal-linguistic appeared at the time of the emergence of legal semiotics (cf. Jackson 1985). It is therefore justified to ask in which relation legal semiotics and legal linguistics stand to each other. The answer to this question largely depends upon the view

\footnotetext{
${ }^{11}$ Classics of legal theory and of related areas of knowledge shaped the conception of contemporary legal linguistics in multiple ways. Certain classical works are mandatory reading for every legal linguist because they make clear the process in which legal linguistics actually emerged. They are however written mainly by scholars who did not perceive themselves as legal linguists. One may bear in mind particularly: François Gény. 1921. Science et technique en droit privé positif, vol. 3, Paris: Sirey (in this book the French term linguistique juridique was used for the first time in the history of this discipline); Georg Henrik von Wright. 1951. Deontic Logics, Mind vol. 60, 1-15; R.M. Hare. 1952. The Language of Morals. Oxford: Clarendon Press; Chaim Perelman, Lucie Olbrechts-Tyteca. 1958. Traité de l'argumentation - La nouvelle rhétorique. Paris: Presses Universitaires de France; H.L.A. Hart. 1961. The Concept of Law. Oxford: Clarendon Press; Alf Ross. 1966. Om ret og retfardighed. En indførelse i den analytiske retsfilosofi. København: Nyt Nordisk Forlag K. Busck; Ronald Dworkin. 1991. Law's Empire. London: Fontana Press; Robert Alexy. 1983. Theorie der juristischen Argumentation. Frankfurt a.M.: Suhrkamp; Aulis Aarnio. 1987. The Rational as Reasonable: A Treatise on Legal Argumentation. Dordrecht: Reidel; Nelson Goodman. 1978. Ways of Worldmaking. Indianapolis: Hackett Publ.; John Langshaw Austin. 1962. How to Do Things with Words? Oxford: Oxford University Press; Jürgen Habermas. 1981. Theorie des kommunikativen Handelns, vol. 1 and 2, Frankfurt a.M.: Suhrkamp. Also, contemporary general legal theory is a source and a benchmark for legal-linguistic studies. It inspires legal-linguistic research that is material (i.e. based on actual analyses of the language in legal contexts) and it evaluates the legal-linguistic research towards its own, non-material, theoretical conceptions of the legal language (cf. Lizisowa 2016: 17, 20; Marmor 2014; Andruszkiewicz 2016).
} 
of the role that legal semiotics plays in general legal studies. Some researchers perceive the legal-semiotic domain as limited to non-verbal communication, for others it concerns explicitly the fundamentals of all communication, and especially verbal communication. Due to the specifics of law, non-verbal communication is limited in it. ${ }^{12}$ Unlike our daily communication, which may be efficient also non-verbally or where substitution of verbal communication is possible by non-verbal action, legal communication is primarily verbal communication. For instance, the French Civil Code is unimaginable in whatever other form of communication that is not a statement in words. One could therefore also assume that there is nothing to show in law. Meanwhile, law as a social phenomenon manifests itself also visually. From gestures of actors in a trial, giggling among the public during court proceedings, judges' robes or their lack, to the architecture of court buildings and custody places, law as a social phenomenon is also constituted by nonverbal elements such as those named. While there is no evidence that the visual aspects of law influence the decisions made by judges, ${ }^{13}$ these elements make clear how law is construed by its authors and those exposed to it. We may furthermore assume that visual aspects of law influence at least non-professionals of law and may be used to intimidate and to discipline citizens, while no corresponding prove is there regarding professionals of law, especially public prosecutors and judges. Another important area of legal-semiotic inquiry in legal linguistics are issues concerning the evaluation of facts in the light of

\footnotetext{
${ }^{12}$ A specific case constitutes the mute law (diritto muto, a term coined by Giuseppe Benedetti. 1999. Diritto e linguaggio. Variazioni sul 'diritto muto', Europa e diritto privato vol. 1, 137-152). In postmodern societies, the use of language, especially in contracting, can be limited to signing preformulated contract terms or buying tickets from a machine without any possibility to negotiate verbally. The mute law is a challenge to legal linguists who primarily focus upon verbal communication.

${ }^{13}$ Attorneys-at-law regularly try to influence juries and judges emotionally by exposing victims of crimes and torts in all their despair and desolation (cf. Hollaris v. Jankowski, 315 Ill. App. 154, 42 N.E. 20859. In this case, the representatives of the plaintiff obliged him to testify in the trial and to stand on one leg, as the plaintiff - a small boy - lost his other leg in a car accident. The judge deciding the appeal in this classical case noticed this move and reacted to it through hardening at least the wording of his decision, if not the decision itself.).
} 


\section{Comparative Legilinguistics 47/2021}

law. ${ }^{14}$ Meanwhile, in my view, the most important area of intersection between legal semiotics and legal linguistics is the one concerning the structure of legal signs in the perspective of meaning emergence in law. Legal semiotics that is based on general semiotics researches the signs of law. General semiotics covers all sign systems, verbal and non-verbal alike. Its main task is to explain how social communicative systems produce signs that enable orientation in society. It proceeds in analogy with the identification of signs in nature. Meanwhile, legal semiotics is

${ }^{14}$ A Swedish court, Uddevalla tingsrätt, had to decide a criminal case in which a 23year old man was accused to have murdered his 17-year old girlfriend (cf. judgment B $3289-19$ of 27 July 2020). The accused denied the crime altogether and refused to provide any explanations concerning the incriminated facts. The facts of this criminal case are not suitable for tender souls: The girlfriend of the accused was reported missing. Therefore, police officers also searched the apartment in which the accused and his girlfriend lived. They found the severed head of the girl concealed in the apartment and some traces of blood on the floor. Subsequently, the man was arrested and accused of murder and of desecration of a corpse. He was convicted on both accounts by the unanimous court. His conviction as such is not controversial as the severed head of the victim found in his apartment provided convincing evidence that he was the murderer notwithstanding his denial. Criminologists estimate the probability rate of criminal guilt in such cases as oscillating at ninety-five percent. Furthermore, the conviction because of the desecration of the corpse of his victim is obvious, both in law and in life, as parts of the body of a deceased person must be buried rather than being stored in premises serving other purposes. Problematic is the sentencing of the accused to lifelong imprisonment (practically this means today in Sweden circa 25 years spent in prison). Yet, according to the Swedish penal law (today amended, yet at the time of the commitment of the murder more lenient), the regular sentence to be expected for murder was between fourteen and eighteen years. According to the interpretation of the penal law given by the Swedish Supreme Court, only in cases of exceptionally brutal and cruel murders could the court sentence the accused to lifelong imprisonment. However, do the facts that are known allow the assumption that we have to do with an exceptionally brutal and cruel murder? The court in Uddevalla decided that this was the case. At this point in the case, a legal-semiotic analysis becomes urgent. It could lay bare the presuppositions made by the court based on the known facts. The only possibility we have when we try to determine the facts of the crime is to visualize the scenery. We cannot reconstruct the criminal act in question with other means because a major part of the victim's body is missing. Therefore, we cannot know how she died. Neighbors heard shouting coming from the apartment, therefore the court assumed that the victim and her aggressor were fighting, the victim lying on the floor, as there were blood traces there. The court further assumed that this struggle caused anguish in the victim to lose her life. In fact, visualization in cases where language is missing (because it cannot emerge) is dangerous in law. Unsurprisingly, the appeal of the accused followed upon the judgment. The court that decided the appeal reduced the criminal sanction to eighteen year of imprisonment due to problems with evidence concerning the above-named circumstances (cf. Hovrätten för Västra Sverige, judgment B 440220 , October 23, 2020). 
not only identifying legal signs, it also scrutinizes the procedures in which we make use of them while trying to communicate, i.e. to understand what signs in isolation or in complex structures actually mean. As the interpretation of signs is one of the central issues of general semiotics, legal semiotics is an underlying methodological layer in all legal-linguistic approaches. Whatever approach to meaning constitution is always semiotic, explicitly or implicitly. Explicit semiotic approaches in legal linguistics are rare, implicit semiotic analyses dominate the contemporary legal-linguistic research. The result of it is that such research is semiotically underdeveloped, as it provides material sources that have a strong semiotic potential, yet this potential remains underexplored in them. In this sense, every article about legal matters that belongs to legal doctrine is implicitly semiotic by the very nature of the phenomenon law that is composed of linguistic signs. Yet only the application of semiotic methods turns such research into truly semiotic exploration. Likewise, language as a set of signs is by necessity a construct that depends on semiotic operations. Therefore, linguistics is a semiotic discipline par excellence. Likewise, legal semiotics is preliminary to all legal-linguistic research. It is the propaedeutic of legal linguistics. In addition, it covers visible aspects of law or legal matters that often remain outside the mainstream interests in legal-linguistic studies.

\section{Legal linguistics and legal logic}

Language as a linguistic concept is rooted in logic. Logical and linguistic analyses are by the nature of things closely interrelated. Therefore, it seems natural to inquire into the logic of the legal language. Legal theoreticians were interested in this issue because they assumed that the act of the application of law could be described as a syllogism that is a logical figure representing reasoning (cf. Kalinowski 1964). Today, we know that syllogistic reasoning does not correspond to the linguistic and logical reality of decision-making processes in the area of law. Enthymeme, known since Aristotle, is better suited to describe the activity of judges. Legal linguists ask how logical relations and constructs are reflected in the legal language. Further aspects of logical implications in the legal language concern deontic modality 
because the legal language is expressed in statutes in the logical form of a norm. Normativity has a specific modality in the legal language that starts with the legal shall or the legal may and covers numerous verbs and related linguistic structures which are used to express the deontic modality in law. ${ }^{15}$ Meanwhile, legal language as a set of signs is dominated by linguistic conventions. It seems therefore that the scrutiny of legal-linguistic conventions that due to the specifics of the legal discourse are ideology-bound may render results that describe the nature of law more fully than the logical analysis of the legal language, which, doubtless, remains a valuable contribution to the clarification of its deep structure.

Logic also contributed another standing topic to legal-linguistic studies. A heritage of the multidisciplinary law and language studies is the analysis of the relation between legal terms and legal concepts. Jurists are interested in concepts because the legal doctrine is practiced since the time of the ancient Romans as conceptual creation and conceptual analysis. Linguists primarily deal with terms as terms directly reflect linguistic reality. In legal linguistics, the reflection upon the relation between legal concepts and legal terms was initiated and developed in the writings by Heikki E.S. Mattila (2012b; 2018). Mattila (2018: 130) defined the legal term as the linguistic expression of a legal concept. Later, research into polysemy and synonymy in the legal

\footnotetext{
${ }^{15}$ Research concerning this issue is impressive in legal linguistics. For instance, the legal shall and the legal may were scrutinized thoroughly in legal-linguistic studies. The problem concerns the specific use of shall and may in English legal texts, e.g. Art. 512 of the U.S. Digital Millennium Copyright Act: "A service provider shall not be liable for monetary relief..." (shall in this sample does not introduce the future tense but stresses that the service provider is not liable according to the law), or: "All rights reserved. This book, or parts thereof, may not be reproduced in any form without written permission of the publishers." In this linguistic sample, the legal may marks action prohibited by law and not an option (cf. Galdia 2017: 162-163). Some words, for instance verbs, which have the undeniable potential to transfer the deontic modality easily, e.g. Polish pozwala się (i.e. it is allowed), are not used for this purpose (cf. Joanna Nowak-Michalska. 2012. Modalność deontyczna $w$ języku prawnym na przykładzie polskiego i hiszpańskiego kodeksu cywilnego. Poznań: Rys. Åke Frändberg (2001. Rättsordningen och rättstillämpningen, in Svensk rätt - en översikt. ed. Strömholm, S., 7-26. Uppsala: Justus) analysed the Swedish modal verbs $f a ̈$, böra, and skola in Swedish legal provisions. Deontic modality in legal texts is conventional and may be expressed with different linguistic means. Overall, legal linguistics is an aggregate of such detailed studies of singular problems and of broader conceptual constructs that structure the whole legal-linguistic domain in a paradigmatically more explicit way. Specific and general studies constitute the legal-linguistic research. They are interrelated like the two sides of the same coin.
} 
language was connected to this definition. Today, these issues might be better elucidated in pragmatic approaches to the legal language where they appear in a different light.

\section{Law and literature}

Law appears primarily in texts. It shares this property with literature. I perceive the scrutiny of law in literature as part of legal linguistics. Some other researchers may see it as an independent area of knowledge that they call law and literature. In essence, the difference in perspective is rather of academic nature as no binding conclusions for legal-linguistic research follow from the alleged dichotomy or from the unity hypothesis. Abundant literature exists about the relation between law and literature, law in literature and the like. ${ }^{16}$ It shows that describing and researching law in non-legal contexts is particularly valuable as this research uncovers the underexplored potentialities of law. Thus, it makes clearer the structure of legal communication that today is limited to the research of explicitly legal texts, with exception of media discourse studies. Legal texts, like literary texts appear in predefined text types. ${ }^{17}$ There is no spontaneous legal text type as there is no spontaneous form in literary works. Statutory texts, court opinions and even witness testimonies follow patterns predefined institutionally by courts or by citizenry at large. Legal linguists study these texts types

\footnotetext{
${ }^{16}$ Cf. Richard Weisberg. 1992. Poethics and Other Strategies of Law and Literature. New York: Columbia University Press; Marta Andruszkiewicz. 2021. The Heritage of Cultural Determinants of Law and Literature: Methodological Findings, International Journal for the Semiotics of Law 34: 611-621; Jeanne Gaakeer. 2012. On the Study Methods of Our Time: Methodologies of Law and Literature, in Intersections of Law and Culture, Gisler, B., Borella, S.S., Wiedmer, C. (eds.). 133-149. UK: Palgrave Macmillan; Julia A. Shaw. 2011. The Continuing Relevance of Ars Poetica to Legal Scholarship and Modern Lawyer, International Journal for the Semiotics of Law vol. $25 / 1,71-93$. In my own writings, chapters on law and literature as part of legal-linguistic studies can be found in Galdia (2014: 265-340) and Galdia (2017: 303-314).

${ }^{17}$ Cf. Jan M. Broekman, 1984. Text als Institution, in Rechtstheorie, Supplement 6, Recht als Sinn und Institution, 145-167; Christer Laurén. 2002. Iconism and Special Language, in The Development of Legal Language. Mattila, H.E.S. (ed.), 11-20. Helsinki: Kauppakaari; Gotti, Maurizio. 2012. Text and Genre, in The Oxford Handbook of Language and Law. Tiersma P.M., Solan L.M. (eds.), 53-66. Oxford: Oxford University Press.
} 
(cf. Lindroos 2015) in an area that I call legal textology. Legal textology is today not uniform and several typologies of legal texts were proposed to date. ${ }^{18}$ Contemporary legal textology goes over into legal discourse analysis that integrates the discussed issues within a broader frame of reference that enables deeper insights.

\section{Linguistic turn in law}

The initial interest in legal-linguistic matters that was mentioned above was captured in different, interrelated approaches such as those described. It also gave rise to a more structured apprehension of the legal language. In turn, the scrutiny of the legal langue provoked a closer interest in law itself. Previously, the analysed law manifested itself mainly in form of the legal doctrine. In the legal doctrine, law was systematized under all but linguistic points of view, although law is primarily a linguistic phenomenon. As in many other areas of knowledge the linguistic turn, i.e. the scrutiny of the object of study in a scientific discipline from the perspective of its language was perceived as promising and finally also brought encouraging results, the same procedure was proposed to take place in legal sciences. The main task of this methodical operation can be called the linguistic turn in law. Until now, the legal doctrine viewed the law in a petrified form, as a set of concepts expressed in provisions where their encoded meaning had to be decoded. The biggest achievement of the attempt to implement the linguistic turn in law was the finding that law is not decoded from the legal provisions but created in numerous legal-linguistic operations (cf. Galdia 2017: 240-270).

\footnotetext{
${ }^{18}$ We may distinguish: the legislative language (statutes), legal decisions including fact description, legal-doctrinal texts, language used by jurists in professional discussions about law and in formal pleadings, language used by laypersons in legal contexts (witness testimony, comments on legal matters), and texts produced by administrative agencies (cf. Galdia 2017: 112). This area necessitates further detailed research as it may be assumed that the origin or circumstances of the use of language might not be the best criterion for distinguishing legal text types. For instance, administrative clerks may express themselves clumsily, while witnesses may use a particularly precise and elaborate language that includes legal terminology. Media language in reports about trials is particularly multifaceted, depending on the specifics of the publication organ and professional skills of journalists.
} 
Law, which was approached in legal linguistics by linguists interested them also as an object that could widen their linguistic horizons. Yet, law proved to be an ungrateful object in terms of profitability for linguistics. It appeared to linguists initially as a language for special purposes, yet which area of knowledge did not develop any special terminology to speak about its object? Only in comparative legal-linguistic studies has the legal language proven somewhat special as no legal language is universal. Additionally, many legal languages are terminologically largely asymmetric. Another finding, this time maybe more spectacular yet also less influential, was the discovery of the ordinary language dimension in the legal language. In fact, legal language can be described today as a language for special purposes with its own terminology and its specific text types. Yet there is no intrinsic necessity in the legal language forcing it to continue this path. Legal communication could also take place in ordinary language, provided the existing legal concepts would be duly transformed and appropriate text types would be proposed to enable this type of communication. Linguists learned a bitter lesson from their scrutiny of the legal language. The initial mystery of legal constructs that fascinated them turned into a mass of obscure, often purposefully misleading statements about the exercise of power in society. No profound well of semantic creation was discovered in it but a shallow pond of capriciously tailored concepts that simply meant something else than words mean in our ordinary speech. Law that was expressed with the means of the legal doctrine simplified our world ruthlessly while decorating the brutal fight for power in society with scholarly erudition. The appropriate reaction to this discovery is not disillusion with the object of legal-linguistic studies but the adjustment of perspective upon the studied object. In fact, methodology comes first in every emerging and expanding discipline, and especially in legal linguistics. The task of legal-linguistic methodology is to provide guidelines in situations such as the one described in this paragraph. I will therefore address now some aspects of the legal-linguistic method. 


\section{Legal-linguistic methodology}

The above sketched aspects of legal-semiotic and legal-logical approaches that are suitable to support the linguistic turn in law further facilitated the emergence of a more consolidated legal-linguistic method. In order to conduct systematic research into the legal language the legal linguist needs a method that responds to his epistemic interests and steers the steps he undertakes when trying to elucidate the legal language. However, legal linguistics cannot refer to a set of methodical rules like established sciences, for instance chemistry. Its method emerges in the doing of the legal-linguistic research towards the background of knowledge assimilated in areas that were described in above paragraphs. Therefore, the research into the legal language can be done in many ways. Particularly challenging for legal linguistics is the identification of methods apt at serving its purpose. As mentioned above, two disciplines deal already with the method for the studies of the language of law. First, interdisciplinary law and language studies use in the discussion of their topics the methods of the involved disciplines, i.e. of law or of linguistics. Forensic linguistics, a sister discipline of legal linguistics, prefers purely linguistic methods. Legal linguistics sets up a method that combines methodical approaches to language and to law in order to elucidate legal problems from its specific point of view. Therefore, it differs from the named areas of knowledge, although it does not necessarily contradict their approaches and results. It is rather methodically complementary, yet also paradigmatically more explicit as it defines more coherently its goals and methods. It also reaches beyond the limits of interdisciplinary approaches and beyond the range of issues discussed in forensic linguistics that is often determined by immediate needs of judicial institutions. It this sense, at least, legal linguistics is an innovation that should broaden and deepen our knowledge of law and of language.

Preliminaries of the legal-linguistic method include numerous choices. Researchers of the legal language will have to determine which concept of language they perceive as best suiting their epistemic interests. Furthermore, they need to determine the concept of law that underlies their studies. Such choices became necessary as neither linguistics nor legal sciences, and especially legal theory, offer us a uniform method. Legal-linguistic studies that neglect preliminary conceptual choices will not be convincing and will not further the goals 
of legal linguistics. Next, the incorporation of the legal component into the legal-linguistic method that I call juridicity will have to take place. Juridicity (one could also call it legalness) comprises all legally relevant aspects of the language of law, mainly its regulation and its treatment in the legal doctrine. Furthermore, the legal-linguistic approach differs from legal approaches that focus mainly upon the legal regulation. For instance, in case of a change in the penal code of a country that abolishes the capital punishment in that country and replaces it with lifelong imprisonment, the change provoked by the amendment will be fundamental in the criminal law doctrine of the concerned country. Meanwhile, for the legal linguist this change may appear insignificant because the language of the law scarcely changes even if the amendment might manifest itself as a part of the legal discourse about law. This discourse may be quite insignificant as well. By contrast, the linguistic modernization of a civil code that does not change the regulation in it, may become a turning point in the development of the legal language of a country. ${ }^{19}$ Therefore, central legal documents such as codes may occasionally be less important in the legal-linguistic research than certain statutes of minor practical importance that reveal legal-linguistically relevant phenomena. Furthermore, the question of legal validity of an analysed legal provision or a court decision is less significant for the legal linguist who searches in the linguistic samples the language of the law. For him, the issue whether a statute is still applicable or whether a court decision was quashed on appeal is secondary to the dominating issue whether it as a linguistic sample that, when researched, reveals a relevant aspect of the legal language. The above sketch of the legal-linguistic methodical fundamentals enables a more coherent view upon the legal language.

\footnotetext{
${ }^{19}$ One might think here about the recent amendments to the French civil code that mainly envisaged its linguistic, and not doctrinal, modernization. In this case, also the legislative efforts to modernize the language of the code proved largely insignificant (cf. Laurent Leveneur (ed.). 2016. Dossier spécial. Code civil. Projet de réforme du droit des contracts, du régime général et de la preuve des obligations. Paris: LexisNexis).
} 


\section{Legal language}

Legal linguistics does not only research itself, i.e. its methodological fundamentals. Primarily, it is expected to research the legal language. Yet, as so often, the object of legal-linguistic studies depends on the methodological determination in the approach adapted by the researcher. The easiest way to determine it is the one by exclusion. Legal linguists generally agree that legal language is different from any natural language because its ontology is of a different sort. It is a language for special purposes, and it is used primarily in social institutions that deal with the creation and the application of law. Meanwhile, its structural background is the ordinary language. Any information expressed in the legal language could also be communicated in ordinary language, as the ordinary language is the basis of our communication. Yet, this is rarely the case in legal institutions. Therefore, today, legal language in its classical shape can be researched as a language for special purposes. Its future nature is open, as tendencies to express socially relevant contents in ordinary language gain momentum in many societies. Particularly interesting in this context is the dynamic zone of status interchange between legal language and ordinary language. On the one side, words of ordinary language acquire new, specific meaning in the legal language (cf. property vs. possession, good faith, free movement of people), on the other side, the specific terminology of the legal language infiltrates ordinary language (cf. presumption of innocence). What is more, the legal language is rooted regularly in another legal language, for instance the terminology of the legal French is based on legal Latin (cf. Mattila 2018: 114). Likewise, the written and the spoken varieties of the legal language influence each other, this time in analogy with spoken and written ordinary language. Meanwhile, the legal language become truly fascinating when it is researched as a tool that accomplishes the emergence of social reality. Indeed, legal language is constitutive of law as legal communication is primarily verbal communication. Unlike the daily communication that occasionally can be efficient in multiple forms of non-verbal action such as gestures, drawings, and mathematical formulae, our law becomes effective exclusively in verbal communication. What is more, in sociolinguistic terms, the legal language belongs to the elaborate code as the professional legal language demands rather advanced linguistic skills. Also, the non- 
professional use of language in the area of law is related to this elaborate code, be it only indirectly. To illustrate, the witness may use ordinary language during his testimony, yet his speech will reflect the professional language of jurists, for instance in (often failed) attempts to speak like them. Legal language is an institutionalized practice and non-jurists are aware of this fact. This finding explains their attempts to adapt their non-professional language to the speech they experience in legal institutions. However, restricted codes, vulgar and grammatically incorrect language may also transfer legal messages correctly. ${ }^{20}$ Meanwhile, the relation between legal communication in grammatically correct and incorrect language remains unexplored in legal linguistics. What is more, the linguistic nature of law does not contradict views developed in social sciences that law is a mechanism of the exercise of power in society. Doubtless, law is not a matter of mere words, but of words used to steer human action in a compulsory way. This ontological feature of law was introduced into legal linguistics by social scientists, as jurists and legal linguists who stand in the tradition of legal positivism or classical structuralism rather avoided this topic and perceived it apparently as being out of scope in legal-linguistic studies. ${ }^{21}$ Meanwhile, more contemporary legallinguistic studies, especially those reflecting the method of critical discourse analysis, incorporate elements of the exercise of power in society into the analysis of the legal language. They show that the mechanism of power exercise is an intrinsic structural element of the language of law. Many legal-linguistic studies do not incorporate this

\footnotetext{
${ }^{20} \mathrm{Cf}$. the series of humorous sketches on the public Swedish television SVT, Suleyman advokat, performed in a Swedish language spoken by immigrants, which only rudimentarily reflects the rules of the Swedish grammar (even the word advokat is spelled adventurously advokatt in the title of the series). The content of the Swedish law is rendered in the short films, which constitute the series, very correctly and comprehensibly, notwithstanding the approximate and whimsical Swedish used for the explanation of legal issues. The short films clearly ridicule this sort of language, yet they also teach a lesson about legal semantics.

${ }^{21}$ Jean-Louis Sourioux and Pierre Lerat (1975) stressed the political character of legal terminology, i.e. its dependence on the state ideology. Jaakko Husa (2007) mentioned in his Kreikan oikeus ja oikeuskieli the intrinsically political element in law that is the exercise of power with linguistic means. Heikki E.S. Mattila (2018: 117) stressed that the legal language serves the purpose of the realization of power. In Mattila's view, this feature of the legal language might be perceived as a specific function of the legal language. Systematic legal-linguistic studies of the exercise of power in law with the help of language may be based upon the concept of power worked out by Michel Foucault (cf. Galdia 2014).
} 
finding into their methods and remain therefore less explicative in their final results.

\section{Monolingual and comparative legal linguistics}

Next to affirmative and critical legal-linguistic studies, legal linguistics is represented in two other types of research. Some researchers engage in the scrutiny of one legal language, others adopt the comparative perspective upon the legal language. Both perspectives upon the legal language brought valuable results (cf. Galdia 2020). The American legal-linguistic tradition whose most prominent representatives were David Mellinkoff (1963) and Peter M. Tiersma (1999) initiated in many parts of the world original legal-linguistic inquiries concerning other languages, although it mainly focused upon legal English, especially upon the problems of the comprehensibility of the legal English towards the background of its historical development. The French pioneers of legal-linguistic studies, Gérard Cornu (2005) as well as Pierre Lerat and Jean-Louis Sourioux (1975) dealt exclusively with legal French. Meanwhile, many of their general findings concern also the legal language as such, and not only the legal French. A group of Russian scholars under A.S. Pigolkin (1990) dealt with the fundamentals of the Russian legal language. Their findings permeate even this essay, in which the Russian legal language is otherwise not mentioned. In Poland, Maria Teresa Lizisowa (2016) developed her communicational theory of law in exclusive reference to legal Polish. Her theory could be also stated in general terms, independently of the legal Polish language. Finally, Deborah Cao (2004) authored a pioneering analysis of legal Chinese, which in its results reaches beyond the main scope of her study. Meanwhile, in a new attempt to broaden the horizon of legallinguistic studies, Heikki E.S. Mattila (2012a; 2013) shaped the comparative legal linguistics in that he combined the methodology of comparative law with comparative linguistics (cf. Lundmark 2012: 51). In the background of all these efforts there is the thesis about the ubiquitous character of the legal language. Therefore, it appears particularly urgent to explore the assumptions of the ubiquity thesis. First, it is assumed in it that the legal language is present in every natural language. Second, it is assumed that the level of professionalism in the 
legal language may differ, i.e. that one legal language may be more professional or abstract than other legal languages on the scale between doctrinally petrified language on the one side and ordinary language on the other side. Third, it is assumed that the communicative tasks are equal in all legal languages. Comparative legal-linguistic research indicates that the ubiquity thesis is a correct epistemic assumption. Monolingual legal-linguistic research did not provide any results that might contradict the main assumptions of the ubiquity thesis. The ubiquity thesis is central to all attempts to generalize legal-linguistic findings. Furthermore, in terms of method, research into a specific legal language may appear easier than a comparative study. Meanwhile, there is no general method of description for all legal languages as their description depends also on some characteristic features or developments that concern the described language. For instance, in the description of the legal Greek, the historical controversy about the use

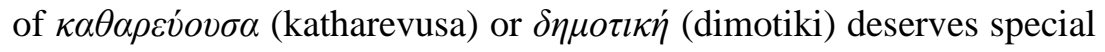
attention of researchers, while there is no such problem in the description of the legal Polish (cf. Galdia 2021). Therefore, a uniform approach to the description of singular legal languages may prove counterproductive and sterile. In comparative linguistics, descriptive approaches are generalized, yet their application comes at a price. This methodological intricacy might also be the reason why some singular legal languages such as legal English or legal Chinese were researched both in the monolingual and in the comparative perspectives. In fact, most great legal languages have been researched in both perspectives and both research perspectives have contributed valuable results. I will now treat some of these results in more detail limiting my efforts to the mainstream current of legal linguistics.

\section{Mainstream legal linguistics, its results and limits}

I call mainstream legal linguistics the dominating current in legallinguistic studies that constitutes the subject of teaching and the object for further research in academic institutions. Mainstream knowledge is beneficial as it forms the basis for professionalism in every area of studies. However, its most unpleasant feature is that it has the tendency to suppress criticism on established knowledge. By so doing, it prevents 


\section{Comparative Legilinguistics 47/2021}

the emergence of alternative intellectual currents that reshape the existing knowledge and propose paradigmatic changes in an area of knowledge. The matter is not a legal-linguistic particularity, yet a scientific regularity and it is mentioned here as such and not as a criticism on the existing currents in the mainstream legal linguistics, mainly because such criticism might be premature. Today, the contours of legal-linguistic methods and topics are clearer than ever. Yet, too many fundamental legal-linguistic issues remain open (cf. Engberg, Kjaer 2011). Is it possible to answer today the question whether there is bad or useless legal linguistics? Are some conceptions of legal linguistics better than others? I would answer in the affirmative, yet also this answer might be perceived as premature in the light of developments in our appreciation of the legal language. At least, I assume that the better an approach to the legal language allows us the apprehend the totality of our speech about law, the higher is its usefulness and also its standing among the existing legal-linguistic approaches. I perceive this finding as a conclusive remark on the relation between mainstream legal-linguistic and alternative approaches to the legal language. Meanwhile, on the more positive side, what did legal linguists find out? What can they profess today as established knowledge about the legal language? First, legal linguistics arrived at the determination of the legal language and its characteristic features that reaches beyond daily experience of professional and nonprofessional speakers of the legal language. We may count among them: precision, informational overload, obscurity, schematized language, formal vocabulary, archaism and solemnity, arcane language, redundant terms, and abbreviations (cf. Galdia 2017: 135-142). Heikki E.S. Mattila (2018: 122-127) perceived as characteristic of the language of law: the frequency of definitions, tautology, information density, abstraction, hypothetical nature (i.e. the timelessness of law that regulates also future factual constellations), neutrality, frequency of references, organized text structure and formalism, frequency of abbreviations, and sentence complexity. Today, all these characteristic features of the legal language may be exposed to further critical scrutiny. First of all, it seems expedient to distinguish between the ideal language of law defined by jurists where precision and timelessness should reign and the reality of the use of language in the area of law where ambiguity, vagueness, and underdetermination of meaning are omnipresent (cf. Poscher 2012: 128-144). In most legal-linguistic studies, the legal language is determined between this dichotomy of 
ideal and reality. It is important to take this dichotomy seriously in all attempts to understand the characteristic features of the legal language. Furthermore, issues of comprehensibility and legal semantics, including lexicology and lexicography were the most general concepts that inspired individual legal-linguistic research from the inception stage of legal-linguistic studies. Problems of comprehensibility of legal texts, which were analysed systematically in the American tradition of legal linguistics, initiated the plain language movement. Projects aiming at the increase of understandability of legal text that were developed within this movement undeniably brought some encouraging results. From the theoretical point of view, it is necessary to mention that the unclarified concept of the plain language that is a language without speakers still causes problems in legal linguistics (cf. Galdia 2017: 296-298). Furthermore, legal lexicology stressed the polysemy and the synonymy in the language of law. Additionally, within the lexicological research into great legal languages, pluricentric legal terminology gained momentum. It was noted that English, Chinese, French, German, Swedish and other legal languages dispose of different, sometimes incongruent terms due to differences among legal systems expressed in these languages. ${ }^{22}$ Furthermore, legal etymology, especially the link between legal languages and legal Latin as well as historical developments in the most influential legal languages are well known today (cf. Mattila 2013). Overall, the best-known characteristic features of the legal language are today those connected to processes in which legal language developed as a language for specific purposes, i.e. in contradistinction to ordinary language. Particularly thoroughly scrutinized remains legal terminology that forms the focal point for legal-linguistic explorations of many researchers.

\footnotetext{
${ }^{22}$ Cf. for legal English Stanisław Goźdź-Roszkowski. 2011. Patterns in Linguistic Variation in American Legal English. A Corpus-Based Study. Frankfurt a.M.: P. Lang; for legal German Marcus Galdia. 1998. Lakisaksa, in Encyclopaedia Iuridica Fennica, vol. VI, Kansainväliset suhteet, 550-555. Helsinki: Suomalainen Lakimiesyhdistys; Artur Dariusz Kubacki. 2014. Pluricentryzm w niemieckim języku standardowym i specjalistycznym, Comparative Legilinguistics vol. 17, 163-181. For legal Chinese in Mainland China, Hong Kong and Taiwan cf. Ho-yan Chan. 两岸三地 (Liang An San Di), vol. 1/2014, vol. 2/2015, vol. 3/2017, Hong Kong: City University of Hong Kong Press.
} 


\section{Newer conceptualizations in legal linguistics}

The scrutiny of the language of law in statutory acts and in court opinions brought results that can be evaluated in the positive and in the negative perspective. Positively, we may mention the discovery of several dimensions of the legal language. ${ }^{23}$ Most important among them are the terminological, the textological, and the discursive dimension. Negatively, legal-linguistic studies made plain that the focus upon the language of legal institutions did not cover the totality of our speaking about law, as many other speakers beyond these institutions speak about law. Their speech might not represent law in terms defined institutionally in democratic states, yet it together with the speech in judicial institutions represents the totality of our speech about law.

\footnotetext{
${ }^{23}$ In many materials, legal language manifests itself strongly, so to say for all to see. In footnote 1 such a typical legal-linguistic case and its outer boundaries were mentioned. As a rule, it concerns the application of a legal statute or a court holding to a factual case, for instance the legal question whether legal proceedings took place 'within a reasonable time' (cf. ECHR judgment 497/17 of 20 June 2020, Chiarello v. Germany). In this court opinion, the European Court of Human Rights (ECHR) had to decide whether criminal proceedings against the defendant that lasted eight years and five months violated his rights under Art. VI of the European Convention on Human Rights (EHRC). This article says: "In the determination of his civil rights and obligations or of any criminal charge against him, everyone is entitled to a fair and public hearing within a reasonable time." Art. VI does not further determine the formulation "within a reasonable time'. Judges need to decide the question when applying the provision of the EHRC to the case. This is the standard legal-linguistic situation that is dealt with in mainstream legal-linguistic studies. More challenging is another question that the ECHR had to decide in the same procedure, namely the issue whether possible damages that the defendant might have suffered were compensated by the fact that in the initial trial a five month segment of the sentence was declared by the court enforced in advance due to the overlong procedure to which the defendant was exposed. This question might be perceived as a purely legal issue. A corresponding legal-factual constellation concerns the question whether a legal intern may be prohibited from wearing a headscarf as a religious symbol when representing the government in a trial (cf. German Constitutional Court's order of 14 January 2020, 2 BvR 1333/17). The prohibition might violate the trainee's constitutional right to exercise her religion freely. In previous approaches to the legal language such issues were neglected as non-linguistic and purely legal. In more contemporary approaches, court decisions concerning such questions are perceived as strictly legal-linguistic as they concern the discursive determination of meaning in law, and not only the clarification of an ambiguous word or formulation in the statutory language. Discursive approaches to legal language enable us to understand law more fully. Paradigmatically, the shift from the analysis of isolated or contextually fixed vocabulary of law to explicit discourse analysis is the fundamental step that constitutes modern legal linguistics.
} 
Traditional legal linguistics neglected this moment while approaching and analysing the language of law. Methodically, it defined the language of law too narrowly and therefore failed in the attempt to describe it convincingly. Today, the language of non-professionals speaking about law, the language of the media reporting legal matters, the language of non-professionals in legally defined contexts, for instance in trials, etc. are scrutinized in order to render more fully the discourse about law. Furthermore, the discourse about the valid law is antagonistic, and it regularly takes place in hostile communicative landscapes. Traditional legal linguistics underestimated this problem as well and subscribed to a fiction where all involved parties aimed with rational argumentative means to reach a just solution to a legal problem. In terms of the legal-linguistic methodology supported in this essay, the traditional legal linguistics underestimated the element of juridicity (legalness) in the linguistic material that it is expected to analyse. Another weakness of the traditional legal linguistics was the approach to law without taking into consideration the element of power in it. In the past, law was regularly analysed in a splendid isolation from one of its fundamental elements, i.e. the exercise of power in society. Even today, many researchers continue to write in this vein. Judicial institutions have the tendency to minimize this aspect and they tend to stress the mechanical application of law as their professional responsibility. This argumentative constant goes back to legal positivism that imagined the judge as a professional who applies internalized legal knowledge to legal problems in the matters he had to decide. His role was defined as decoding of the encoded messages in statutory law and in legal decisions of other courts. According to this view, the better the judge knew the law, the easier it was for him to decode the encoded meaning in statutory provisions correctly and to apply it strictly, i.e. mechanically to the case he had to decide. Meanwhile, already the general legal theory signaled that the application of law is a creative act where argumentation and interpretation decide about the legal meaning within different ethical frames of reference, thus engendering differing, and often also 
contradictory decisions. ${ }^{24}$ Theoreticians of law discovered that there was no one right decision in law (cf. Aarnio 1987; Dworkin 1991). Traditional legal linguistics did not take this discovery seriously. Time has come to widen the scope of legal-linguistic studies methodically and materially. Pragmatic legal linguistics emerged as an answer to the deficiencies described in this paragraph. Therefore, in the follow up to this review essay I will deal with pragmatic legal linguistics.

${ }^{24}$ In the decision Olympic Airways v. Hussain (540 U.S. 644, 2004) the U.S. Supreme Court had to decide whether an airline was liable for wrongful death of a passenger who died on board after being refused by a flight attendant to change his seat and move to a place where cigarette smoke penetrated less invasively. The passenger suffered of asthma and booked a seat in the non-smoking section of the plane (in times when smoking was still allowed on international flights). Yet, too much smoke invaded the non-smoking section and the passenger got respiratory problems. He got support from a medical doctor but died sometime later. His widow referred in her suit to Article 17 of the Warsaw Convention and demanded damages from the airline. Article 17 of the Warsaw Convention says: "The carrier is liable for damage sustained in the event of the death or wounding of a passenger or any other bodily injury suffered by a passenger, if the accident which caused the damage so sustained took place on board the aircraft or in the course of any of the operations of embarking or disembarking." It is problematic whether an accident happened on board the aircraft in our case. The airline says no, as nothing extraordinary happened on board, the widow says yes, as the passenger was not allowed to take another seat and died because of this refusal. The court refers for orientation to a definition of accident from a precedent (Air France v. Saks, 470 U.S. $392,1985)$, saying that an accident is "an unexpected or unusual event or happening that is external to the passenger." Meanwhile, the decision of the court finally follows the policy established to further certain social goals. In fact, there is no one right solution to such cases, notwithstanding their meticulous linguistic analysis. We have here to do with a decision that will convince some jurists and non-professionals of law more than the contrary decision, as at least two well founded solutions are thinkable in this case. In other words, none of the two thinkable decisions appears irrational. Reasonableness of the final decision of the U.S. Supreme Court is rooted in the rationality established along ideological lines. Research into legal argumentation seems to be fundamental to the legal-linguistic analysis of this case, cf. Aarnio, Aulis. 1989. Das regulative Prinzip der Gesetzesauslegung. Überlegungen zum Problem der Möglichkeit der einzig richtigen Entscheidung, Rechtstheorie vol. 20, 409-431. Legal linguistics has to develop methods that would be able to cope with legal arguments developed along the lines of legal rationality because the legal language functions as a vehicle of legal rationality. 


\section{Friends and foes of legal linguistics}

Legal linguistics is an area of professional activities. Meanwhile, it is rarely exercised by scholars who deal exclusively with legal-linguistic issues. The reason for this situation is the lack of institutional support for legal linguists. Paradoxically, as a part of the social segment of society that is committed to progress, the established academia did not always welcome the newly emerged area of legal-linguistic studies. It is a structural constant in the scientific exploration of nature and society that progress and innovation are not generally welcome, yet as a rule they cannot be prevented either. Progressive and regressive forces in the academic discourse and in academic institutions, paradigmatic continuity and discontinuity, as well as methodological twists and tilts shape the reality of intellectual exploration of man in the world. Therefore, it might have been vain to expect general enthusiasm in the moment of emergence of legal linguistics from the amalgam of legal and linguistic issues and methods. Today, legal linguistics is slightly better positioned on the scale of academic disciplines. Yet, it remains rather marginal in legal studies and in linguistics proper, although it emerged with the ambitious aim to restructure our perspective upon law through researching its language. In legal sciences, its existence is sometimes ignored, and the number of academic positions devoted to the study of legal language is minimal when compared for instance with the number of tenures in legal history or in property law. Finally, while the legal-linguistic research brought up a vast amount of valuable results, these results are at best contemplated in isolation and have no impact upon the teaching and the researching of law in law schools. Strategically, legal linguistics of the future will have to balance this structural deficiency.

\section{Conclusions}

Scholarly interest in matters related to legal language shaped a new area of knowledge called in this essay legal linguistics. Unsystematic knowledge about legal language has longer roots and reaches back to antiquity. Meanwhile, precisely formulated research programmes and 
studies of the legal language emerged relatively late, only in the course of the twentieth century. They resulted in the accumulation of knowledge that enables today to teach and to research legal language systematically. Legal-linguistic research that initially concerned some selected topics that were deemed as characteristic features of the legal language expanded into an area of knowledge covering today all socially relevant aspects of language use in law. Paradigmatically, the shift from analysing legal vocabulary to discourse analysis enabled the emergence of modern legal linguistics. This modern legal linguistics expanded its domain of research to cover all linguistically relevant operations in law. Therefore, it almost coincides with law and with legal studies. It could be also called a specific theory of law. From the legallinguistic perspective, legal linguistics features the most relevant theory of law, i.e. the theory of the legal language. It enables description and understanding of law in broadest social contexts. It would be difficult to demand more from an area of knowledge.

\section{References}

In the references, only publications concerning general aspects of legal linguistics are listed. Literature concerning specific legal-linguistic issues is provided in Additional materials mentioned in footnotes.

Aarnio, Aulis. 1987. The Rational as Reasonable: A Treatise on Legal Justification. Dordrecht: Reidel.

Andruszkiewicz, Marta. 2016. On Some of the Aspects of the Linguistic Theory of Law. Studies in Logic, Grammar, and Rhetoric vol. 49: 221-229.

Cao, Deborah. 2004. Chinese Law. A Language Perspective. Aldershot: Ashgate.

Cornu, Gérard. 2005. Linguistique juridique. 3d ed. Paris: Montchrestien.

Dworkin, Ronald. 1991. Law's Empire. London: Fontana Press.

Engberg, Jan, Kjaer, Anne Lise. 2011. Approaches to Language and the

Law - Some Introductory Notes. Hermes - Journal of Language and Communication Studies vol. 46: 7-10.

Galdia, Marcus. 2014. Legal Discourses. Frankfurt a.M.: Peter Lang. 
Galdia, Marcus. 2017. Lectures on Legal Linguistics. Frankfurt a.M.: Peter Lang.

Galdia, Marcus. 2020. The Comparative Element in Comparative Legal Linguistics. Comparative Legilinguistics vol. 43: 57-76.

Galdia, Marcus. 2021. Legal Constructs. Reflections upon LegalLinguistic Methodology. Poznań: Wydawnictwo Rys.

Gibbons, John. 2003. Forensic Linguistics. An Introduction to Language in the Justice System. Oxford: Blackwell.

Husa, Jaakko. 2015. A New Introduction to Comparative Law. Oxford/Portland: Hart.

Husa, Jaakko. 2020. Language of Law and Invasive Legal Species Endemic Systems, Colonisation and Viability of Mixed Law. Global Journal of Comparative Law vol. 9: 149-182.

Jackson, Bernard S. 1985. Semiotics and Legal Theory. London/Boston: Routledge \& Kegan Paul.

Kalinowski, George. 1964. Introduction à la logique juridique: éléments de sémiotique juridique, logique des normes et logique juridique. Paris: Librairie générale de droit et de jurisprudence.

Kozanecka, Paulina, Matulewska, Aleksandra, Trzaskawka, Paula. 2017. Methodology of Interlingual Comparison of Legal Terminology. Towards General Legilinguistic Translatology. Poznań: Wydawnictwo Naukowe Contact.

Lindroos, Emilia. 2015. Im Namen des Gesetzes. Eine vergleichende rechtslinguistische Untersuchung zur Formelhaftigkeit in deutschen und finnischen Strafurteilen. Rovaniemi: Lapin yliopisto.

Lizisowa, Maria Teresa. 2016. Komunikacyjna teoria języka prawnego. Poznań: Wydawnictwo Naukowe Contact.

Lundmark, Thomas. 2012. Charting the Divide Between Common and Civil Law. Oxford: Oxford University Press.

Marmor, Andrei. 2014. The Language of Law. Oxford: Oxford University Press.

Mattila, Heikki E.S. 2002. Towards the Science of Legal Linguistics. In The Development of Legal Language, Mattila, H.E.S. (ed.), 167-191. Helsinki: Kauppakaari.

Mattila, Heikki E.S. 2012a. Jurilinguistique comparée: Langage du droit, latin et langages modernes. Montréal: Y. Blais. 
Mattila, Heikki E.S. 2012b. Legal Vocabulary. In The Oxford Handbook of Language and Law, Tiersma, P.M., Solan, L.M. (eds.), 27-38. Oxford: Oxford University Press.

Mattila, Heikki E.S. 2013. Comparative Legal Linguistics. Language of Law, Latin and Modern Lingua Francas, $2^{\text {nd }}$ ed. Aldershot: Ashgate.

Mattila, Heikki E.S. 2018. Legal Language. In Languages for Special Purposes, Humbley, J., Budin, G., Laurén, C. (eds.), 113-150. Berlin/Boston: W. de Gruyter.

Matulewska, Aleksandra. 2013. Legilinguistic Translatology. A Parametric Approach to Legal Translation. Bern: P. Lang.

Mellinkoff, David. 1963. The Language of the Law. Boston/Toronto: Little, Brown \& Co.

Pigolkin, A. S. (ed.). 1990. Jazyk zakona. Moskva: Juridicheskaya literatura.

Poscher, Ralf. 2012. Ambiguity and Vagueness in Legal Interpretation. In The Oxford Handbook of Language and Law, Tiersma P.M., Solan L.M. (eds.), 128-144. Oxford: Oxford University Press.

Salmi-Tolonen, Tarja. 2008. Language and the Functions of Law. Rovaniemi: University of Lapland.

Sourioux, Jean-Louis, Lerat, Pierre. 1975. Le langage du droit. Paris: Presses universitaires de France.

Tiersma, Peter M. 1999. Legal Language. Chicago: University of Chicago Press.

\section{Additional materials mentioned in footnotes}

Aarnio, Aulis. 1989. Das regulative Prinzip der Gesetzesauslegung. Überlegungen zum Problem der Möglichkeit der einzig richtigen Entscheidung, Rechtstheorie vol. 20: 409-431.

Alexy, Robert. 1983. Theorie der juristischen Argumentation. Frankfurt a.M.: Suhrkamp.

Andruszkiewicz, Marta. 2021. The Heritage of Cultural Determinants of Law and Literature: Methodological Findings, International Journal for the Semiotics of Law 34: 611-621. https://doi.org/10.1007/s11196-020-09743-4. 
Austin, John Langshaw.1962. How to Do Things with Words? Oxford: Oxford University Press.

Beaudoin, Louis. 2002. Legal Translation in Canada. In The Development of Legal Language, H.E.S. Mattila (ed.), 115-130. Helsinki: Kauppakaari.

Benedetti, Giuseppe. 1999. Diritto e linguaggio. Variazioni sul 'diritto muto', Europa e diritto privato vol. 1: 137-152.

Broekman, Jan M. 1984. Text als Institution. In Rechtstheorie, Supplement 6, Recht als Sinn und Institution, 145-167.

Chan, Ho-yan. 2014. 两岸三地 (Liang An San Di), vol. 1. Hong Kong:

City University of Hong Kong Press.

Chan, Ho-yan. 2015. 两岸三地 (Liang An San Di), vol. 2. Hong Kong:

City University of Hong Kong Press.

Chan, Ho-yan. 2017. 两岸三地 (Liang An San Di), vol. 3. Hong Kong:

City University of Hong Kong Press.

Dölle, Hans. 1949. Vom Stil der Rechtssprache. Tübingen: Mohr.

Felder, Ekkehard, Vogel, Friedemann (eds.) 2017. Handbuch Sprache im Recht. Berlin: Walter de Gruyter.

Frändberg, Åke. 2001. Rättsordningen och rättstillämpningen. In Svensk rätt - en översikt, ed. Strömholm, S., 7-26. Uppsala: Justus.

Gaakeer, Jeanne. 2012. On the Study Methods of Our Time: Methodologies of Law and Literature. In Intersections of Law and Culture, Gisler, B., Borella, S.S., Wiedmer, C. (eds.), 133149. UK: Palgrave Macmillan.

Galdia, Marcus. 1998. Lakisaksa, in: Encyclopaedia Iuridica Fennica, vol. VI, Kansainväliset suhteet. 550-555. Helsinki: Suomalainen Lakimiesyhdistys.

Galdia, Marcus. 2013. Strategies and Tools for Legal Translation. Comparative Legilinguistics vol. 16: 13-29.

Geer, Louis de. 1985 (1853). Om den juridiska stilen. Stockholm: Rediviva.

Gény, François. 1921. Science et technique en droit privé positif, vol. 3. Paris: Sirey.

Goodman, Nelson. 1978. Ways of Worldmaking. Indianapolis: Hackett Publ.

Gotti, Maurizio. 2012. Text and Genre. In The Oxford Handbook of Language and Law, Tiersma P.M., Solan L.M. (eds.), 53-66. Oxford: Oxford University Press. 
Goźdź-Roszkowski, Stanisław. 2011. Patterns in Linguistic Variation in American Legal English. A Corpus-Based Study. Frankfurt a.M.: P. Lang.

Großfeld, Bernhard. 1997. Sprache und Schrift als Grundlage unseres Rechts, Juristenzeitung 1997/633-646.

Großfeld, Bernhard. 1990. Unsere Sprache: Die Sicht des Juristen. Opladen: Westdeutscher Verlag.

Grunau, Martin. 1961. Spiegel der Rechtssprache. Flensburg: Verlag Kurt Gross.

Habermas, Jürgen. 1981. Theorie des kommunikativen Handelns, vol. 1 and 2. Frankfurt a.M.: Suhrkamp.

Hare, R.M. 1952. The Language of Morals. Oxford: Clarendon Press. Hart, H.L.A. 1961. The Concept of Law. Oxford: Clarendon Press.

Husa, Jaakko. 2007. Kreikan oikeus ja oikeuskieli. Helsinki: Suomalainen Lakimiesyhdistys.

Javornik-Čubrić, Marijana. 2018. Što je pravna lingvistika, Lingua Montenegrina vol. 22: 31-37.

Kubacki, Artur Dariusz. 2014. Pluricentryzm w niemieckim języku standardowym i specjalistycznym, Comparative Legilinguistics vol. 17: 163-181.

Laurén, Christer. 2002. Iconism and Special Language. In The Development of Legal Language. Mattila, H.E.S. (ed.), 11-20. Helsinki: Kauppakaari.

Leveneur, Laurent (ed.) 2016. Dossier spécial. Code civil. Projet de réforme du droit des contracts, du régime général et de la preuve des obligations. Paris: LexisNexis.

Mimin, Pierre. 1970. Le style des jugements. $4^{\text {th }}$ ed. Paris: Librairies Techniques.

Nowak-Michalska, Joanna. 2012. Modalność deontyczna w języku prawnym na przyktadzie polskiego $i$ hiszpańskiego kodeksu cywilnego. Poznań: Wydawnictwo Rys.

Perelman, Chaim, Olbrechts-Tyteca, Lucie. 1958. Traité de l'argumentation - La nouvelle rhétorique. Paris: Presses Universitaires de France.

Prieto Ramos, Fernando. 2015. Quality Assurance in Legal Translation: Evaluating Process, Competence and Product in the Pursuit of Adequacy, International Journal for the Semiotics of Law vol. 28 (1): 11-30. https://doi.org/10.1007/s11196-014-9390-9.

Ross, Alf. 1966. Om ret og retfcerdighed. En indførelse i den analytiske retsfilosofi. København: Nyt Nordisk Forlag K. Busck. 
Schauer, Frederick (ed.). 1993. Law and Language. Aldershot/Hong Kong: Dartmouth.

Schönherr, Fritz. 1985. Sprache und Recht. Aufsätze und Vorträge.

Wien: Manz'sche Verlags- und Universitätsbuchhandlung.

Schroeder, François Michel. 1978. Le nouveau style judiciaire. Paris: Dalloz.

Shaw, Julia A. 2011. The Continuing Relevance of Ars Poetica to Legal

Scholarship and Modern Lawyer, International Journal for the

Semiotics of Law vol. 25/1: 71-93.

Tiersma, Peter M., Solan, Lawrence M. (eds.) 2012. The Oxford Handbook of Language and Law. Oxford: Oxford University Press.

Vogel, Friedemann (ed.) 2019. Legal Linguistics Beyond Borders: Language and Law in a World of Media, Globalisation and Social Conflict. Berlin: Duncker \& Humblot.

Wedberg, Birger. 1928. Lagstil. Några citat och reflektioner. Stockholm: Norsted.

Weihofen, Henry. 1980. Legal Writing Style. $2^{\text {nd }}$ ed. St. Paul: West Publishing Co.

Weisberg, Richard. 1992. Poethics and Other Strategies of Law and Literature. New York: Columbia University Press.

Wright, Georg Henrik von. 1951. Deontic Logics, Mind vol. 60: 1-15. 